\title{
Behavioral Change and Family Disruption among Labor Migrants in Nepal
}

\author{
Ram Raj Pokharel*
}

\begin{abstract}
Sociological studies of migration are diverse. The motive for international labor migration includes political, economic, social, and environmental cause. In this regard, this study aims to explore the behavioral change among the labor migrants and the status of family disruption of the Nepalese involved in foreign labor migration. The study has been based on primary source, data collected from interview schedule by fulfilling the validity from the review of literature with the sample from Tribhuvan International Airport, and migrant returnee's temporary residences such as hotels and guest house on accidental basis. The sample includes 102 respondents. The study concludes that the there is a behavioral change among the family members of the migrant labors. The study further concludes there has not been the family disruption among the family members of the migrant labors.
\end{abstract}

Key words: Behavioral change, family disruption, Labor migration

\section{Introduction}

Movement of the human beings started in search for food, shelter and resources in the human history. Migration of people has been a common phenomenon since the beginning of human civilization. Then migration is purely a socio- cultural and economic phenomenon, which is the result of complex mechanism involving social, physical, political, institutional and other determinants. However, migration is guided by individual behavior and decision, it is not possible to determine migration as it has diverse characteristics (Revenstein, 1885). The population of Nepal as of census day; June 22, 2011 stands at 26.6 millions. The annual average growth of population is 1.35 percent. Absent population of Nepal is recorded as 1.92 million against 0.762 millions in 2001 census (Central Bureau of Statistics, 2012).

In Nepal also, a family and individual division that is divided to migrate, because all individual with similar social, economic and other characteristics do not migrate, people in village move in search for employment because of low income. With increasing numbers of people moving from one country to another, most of the people migrate from their origin to abroad in search of better living for the migrant and the family members. In fact, unemployment; low wages, meager career prospects for highly educated people, significant country risk for national investors in the home country are all factors that people want to emigrate abroad. Migration

*Lecturer, Faculty of Humanities Tribhuvan University 
for employment means a person who migrates from one country to another with a view to being employed otherwise than on his own account and includes any person regularly admitted as a migrant for employment (Ghimire, 2008).

Industrialized countries are interested in the recruitment of migrants from poor countries for physical labor and the migrants are often provided with short term contracts. The poor economic condition, low productivity, low land holding are the some supply-push factor and globalization and development process in general are the demand-pull factor for the migration of labor, such migration, which has played significant role by transferring funds to their home countries, has characterized much been used by migrant families for personal consumption, to finance education of relatives left behind, to pay for the cost of migration and to invest funds for other purposes. South Asian countries are the main suppliers of migrant workers to the Gulf, East Asian, Europe and American nations. Migration and development are closely interlinked. Human development report 2009 rightly points out, "migration can contribute to human development, especially if the rights of movers are improved" (UNDP, 2009).

The history of formal entrance of Nepalese citizens in foreign employment begins in 18141815 after the Nepal-British India war. A total of 4,650 Nepalese youngsters were recruited to the British armed forces as a British-Gurkha regiment (Battarai \& Regmi, 2012) . Similarly, the migration of Nepalese people for other employment purpose begins to work in the tea states of Darjeeling and forest of Assam by the second half of the 19th century. Economic migration to the Middle East from South Asia and other parts of the world was spurred-on by the oil boom in the early 1970s. The reasons behind the migration are almost same in Nepal as other parts of the world. Existing poverty, limited employment opportunities, deteriorating agricultural productivity, armed conflict are some of the reasons about the motives behind international migration. There are many villages in Nepal where the migration has been established as a culture of community to go aboard for work for a while and return back with some money and experience of placement in different geographical location. The influence of friends, relatives and well-wishers has also played a prominent role to the promotion of international migration (Battarai \& Regmi, 2012) .

The history of formal labor administration in Nepal is about 70 years old. Its origin can be traced to the start of organized industry in the 1930's, but national structures took from only after the out break of the 1947 labor movement in Biratnagar. With the installation of a democratic government in 1951, the labor administration underwent a process of reform to cope with increase labor problems and to undertake labor welfare measures. The establishment of regional labor offices in the 1960s began with the creation of the first labor office in Biratnagar under the department of industry. In the past government of Nepal has adopted no specific policies to deal with foreign employment. In the 1740s, the process of unifying Nepal provoked large scale foreign migrations (Gurung, 2004). Unification brought hardship to peasants and to the poor in the form of corvee labor, over taxation and exploitation from state agencies and their functionaries. As a consequence mass numbers of people migrated to India, where newly 
established tea states and opening of land in Assam, Sikkim and Nagaland have made work available. While British rule in India was encouraging such immigrants, the Government of Nepal faced a shortage of labor and initially attempted to discourage laborers from seeking work abroad (Gurung, 2004).

After the restoration of democracy in 1990 the flow shifted, when Nepal government introduced new foreign labor policy in Nepal. The perception of Nepalese migrants has radically shifted from " Global Warriors to Global Workers" during the last few decades. Existing poverty, limited employment opportunities, deteriorating agriculture productivity and armed conflict are some of the reasons behind international labor migration. Most rural household in Nepal depends on the earnings of at least one family member who is employed away from home. Nepalese migrants, especially from middle or low class families, are migrating temporarily to different countries. It has been estimated that in recent years more than 1500 Nepalese people per day go abroad for foreign employment (Battarai \& Regmi, 2012).

Nepal Human Rights Commission (NHRC) found that two-third of Nepal working overseas was employed in the Gulf countries, mainly in Saudi Arabia 42\%, Qatar 11.5\% and United Arab Emirates 9\%. Most of the Nepalese migrants in the Gulf countries are involved in heavy manual labor on road building sites or construction sites, often in high temperatures. The government of Nepal prohibited new registration of new female migrants for traveling to work in Gulf countries in 1998 to ensure against the physical and sexual abuse. As the government of Nepal has lifted the ban in 2003, female migrants are allowed to work in the organized sector such as in hospitals, hotels and shops (Nepal Human Rights Commission, 2012).

In recent year, remittances emerged as one of the premier sources of foreign exchange through foreign employment that will have significant bearing on the economic development of Nepal, especially in the context of poverty alleviation (Shrestha, 2001).

Social challenges including displacement, adjustment and adaption within the destination countries and back at home are not easy to measure and map out. However, the potentiality is severe and far reaching. Social effects of migration on families and Nepali society as a whole justify an in-depth exploration of the subject. It is essential to improve understanding of the socio-cultural impact in labor migration. The information, thus, generated will help to identify policy gaps and areas requiring improved institutional support.

\section{Objectives}

The overall objective of this study is to determine the behavioral change among the labor migrants in Nepal. Similarly, the specific objective of the study is to analyze the status of family disruption of the Nepalese involved in foreign labor. 


\section{Methodology}

This seminar paper is prepared by using primary data, collected from interview schedule and secondary data were taken from previous studies, published books and other related literature.

\section{Sampling procedure}

The sample size of the study was 102 migrant returnees from different countries excluding the labors in India. The samples were selected at Tribhuvan International Airport (TIA), which have been taken using accidental sampling method. Due to lack of formal data on foreign labor migration especially the migrant returnees, this sampling procedure would be more reliable. The most of the international migrant workers use this airport for departure and arrival to their destination. The researcher has visited the migrant returnee's temporary residences such as hotels and guest house where they spend some days before leaving to the hometown.

\section{Result and Discussion}

\section{Household size of migrant returnees}

The size of household is one of the economic characteristics. So, this particular variable has been taken into consideration. Total 102 migrant returnees' information on the size of population and household was studied for the purpose of research. In those household, total population was 916 and among them 456 were males and 460 were females. The following table shows the details of household size and population of migrant returnees.

Table 1: Distribution of household size

\begin{tabular}{|l|c|c|c|c|}
\hline Household size & $\begin{array}{c}\text { No of migrant } \\
\text { returnees }\end{array}$ & Male & Female & Percent \\
\hline $0-4$ & 12 & 90 & 92 & 11.8 \\
\hline $5-9$ & 62 & 250 & 258 & 60.8 \\
\hline $10-14$ & 20 & 100 & 90 & 19.6 \\
\hline $15-19$ & 4 & 10 & 12 & 3.9 \\
\hline 20 and above & 4 & 6 & 10 & 3.9 \\
\hline Total & 102 & 456 & 460 & 100 \\
\hline
\end{tabular}

Source: Field Survey, 2019

There was highest in 5-9 people in household which contains 60.8 percent followed by 10-14 people 19.6 percent. 11.8 percent household have 0-4 people while 3.9 percent household have 15-19 and 20 and above people. In the sex composition, female percentage 55.22 is higher than the male percentage 49.78 . This shows that there was very large household size in few household in migrant returnees' area where as three or four generations are in combined family. It has been noticed that the family size is the significant of joint family structure of society. In the total population of Nepal female number is higher than male and similarly the research has been reflected such findings. 


\section{Age composition of migrant returnees}

The age and sex composition is the basic characteristic of population. Age is the major factor associated with active population. The age between 15 to 59 is consider economically active population. All the aspects of individuals such as social, cultural and economic activities are affected by age of an individual. The interview schedule was prepared to asks the migrant returnees to collect the data on their personal as well as household information. Out of 103 migrant returnees, 86 were male and 16 were female. Classification of age group of the male and female migrants returnees are given below.

Table 2: Age composition of migrant returnees

\begin{tabular}{|l|c|c|}
\hline \multicolumn{1}{|c|}{ Age group } & No of population & Percent \\
\hline $15-20$ & 18 & 17.6 \\
\hline $21-25$ & 35 & 34.3 \\
\hline $26-30$ & 25 & 24.6 \\
\hline $31-35$ & 15 & 14.8 \\
\hline $36-40$ & 5 & 4.9 \\
\hline $41-45$ & 3 & 2.9 \\
\hline $45-$ above & 1 & 0.9 \\
\hline Total & 102 & 100.0 \\
\hline
\end{tabular}

Source: Field Survey, 2019

The highest 34.3 percent was the 21-25 age group of migrant returnee and was followed by the 24.6 of 26-30 age group. 17.6 percent of 15-20 remained the third age group and 14.8, 4.9 , and 2.9 percent by $31-35,36-40$ and $41-45$ age group respectively. The lowest percentage was more than 45 and above age group is 0.9 percent. It shows that the age of 21 to 25 years was highly potential population to go to abroad. The male percentage to go to abroad was 84.3 and female percentage was 15.7.Mostly males' number is the dominated in the foreign labor job. In patriarchal Nepalese society, they are responsible to look after the family. The female workers percentage shows that the traditional Nepalese society is being open and they start to seek new space in abroad. In the beginning, only males were involved in abroad employment. However, the tradition is being changed in new era. So, the females are also going to abroad for employment.

\section{Status of migrant returners}

Education plays a pivotal role in the life of an individual as well as in the family status. The educational status of respondents was collected to show the education attainment of migrant returnees. The education influences the socio-economic and demographic status of a person in his/her life. The following table shows the educational status as follows. 
Table 3: Educational status of respondents

\begin{tabular}{|l|c|c|}
\hline Education & No of migrant returnees & Percent \\
\hline Illiterate & 10 & 9.8 \\
\hline Literate & 40 & 39.2 \\
\hline Primary & 20 & 19.6 \\
\hline Secondary & 20 & 19.6 \\
\hline SLC & 6 & 5.9 \\
\hline Higher secondary & 6 & 5.9 \\
\hline Total & 102 & 100.0 \\
\hline
\end{tabular}

Source: Field Survey, 2019

The Table 3shows that 39.2\% migrant are literate i.e. can read and write while only 9.8\% labor migrant are illiterate and are involved in domestic worker, construction worker. And19.6\% migrant labor passed primary and secondary level education. Finally 5.9\% passed SLC and higher education.

\section{Caste and ethnicity of the respondents}

Nepal is multi caste and ethnic country. According to 2011 census there are 125 different caste and ethnic people in Nepal. The following table shows the caste and ethnic distribution of the study population.

Table 4: Distribution of caste and ethnicity

\begin{tabular}{|l|c|c|}
\hline \multicolumn{1}{|c|}{ Caste/ethnicity } & No of respondents & Percent \\
\hline Brahmin & 10 & 9.8 \\
\hline Chhetri & 26 & 25.5 \\
\hline Janajati/Madhesi & 52 & 50.9 \\
\hline Dalit & 10 & 9.8 \\
\hline Others & 2 & 2.0 \\
\hline Total & 102 & 100.0 \\
\hline
\end{tabular}

Source: Field Survey, 2019

The largest labor return population was janajati/madhesi $50.9 \%$ which was followed by chetri 25.5 percent, Brahmin and dalits were equal in percentage 9.8 and 2.0 percent was categorized as others. The janajati and chhetries are the main dominant caste in the national level. In this study, they were engaged as a higher percentage in international labor migration for the employment. Thus, it can say that the ethnic and madhesi people are highly interested in the abroad job rather than work within the country.

\section{Destination of migrant labor}

Government of Nepal has opened 109 countries for labor migration. It is considered that the 50 percentage of the migrant workers of Nepal remain in India for employment, but in 
this study of labor migration is only focused beside the India. The following table shows the destination of migrant labor.

Table 5: Destination of migrant labor

\begin{tabular}{|l|c|c|}
\hline \multicolumn{1}{|c|}{ Countries } & No of migrant returnees & Percent \\
\hline Malaysia & 38 & 37.3 \\
\hline Gulf countries & 40 & 39.3 \\
\hline East Asia & 8 & 7.8 \\
\hline Europe & 8 & 7.8 \\
\hline America & 2 & 1.9 \\
\hline South Korea & 6 & 5.9 \\
\hline Total & 102 & 100.0 \\
\hline
\end{tabular}

Source: Field Survey, 2019

Around one third, 39.3\% people were migrated to Gulf Countries which was followed by Malaysia 37.3percent. 7.8 percent to Europe as well. 1.9 percent was migrated in America and 5.9 percent to South Korea. The easy destination for migrant worker was Gulf countries though the working condition is not easy due to warm climate and socio-cultural rigidity. Due to the friendly climate, Malaysia is considered as the lucrative destination for the job seeker. The trend of migration to East Asia, Europe and American countries is very few due to the difficulty in visa approval.

\section{Causes of migration}

Nepalese youth are flying daily from Tribhuvan International Airport of Kathmandu for employment opportunities in foreign countries. There are many causes for people to migrate for jobs in foreign countries. The following data shows the causes of migration of people for foreign countries for jobs.

\section{Table 6: Causes of migration}

\begin{tabular}{|l|c|c|}
\hline \multicolumn{1}{|c|}{ Causes of migration } & No of respondents & Percent \\
\hline Unemployment & 32 & 31.4 \\
\hline Poverty & 40 & 39.2 \\
\hline More income & 6 & 5.9 \\
\hline Trends & 4 & 3.9 \\
\hline Child education & 20 & 19.6 \\
\hline Total & 102 & 100.0 \\
\hline
\end{tabular}

Source: Field Survey, 2019

The main causes of migration were poverty which constituted 39.2 percent while 31.4 percent people were migrated due to lack of jobs in the home country. 5.9 percent people were migrated for more income and 3.9 percent due to trends to earn more or being unemployment. 19.6 percent people were for children education and they wanted to improve their children's 
education with more income. The unemployment rate was also higher in Nepal so youth want to migrate in abroad. Major reasons for labor migration are unemployment and poverty. Similarly, social discrimination, lack of opportunity, displacement due to natural or created disaster, political instability are also major factors for migration. On the other hand, people are trying for gainful employment. They want to stay in that place where they can enjoy benefit of development, feel security, peace and equality. Sometimes, people are attracted by others earnings and make dreams with high aspect ions. It is the reason; global trend of migration is increased day by day (Hass, 2010).

\section{Feeling towards migration}

Foreign labor migration has great contribution in advancing the household as well as national economy. People are thinking it is a way to reduce poverty in rural areas and in country as to be ideal in own country without jobs all the people are not happy and their feeling is not satisfactory towards migration of family members.

Table 7: Feeling towards migration

\begin{tabular}{|l|c|c|}
\hline Feeling & No of respondents & Percent \\
\hline Good & 62 & 60.8 \\
\hline Bad & 32 & 31.4 \\
\hline Not bad & 8 & 7.8 \\
\hline Total & 102 & 100.0 \\
\hline
\end{tabular}

Source: Field Survey, 2019

Three-fifth respondents were feeling and thinking migration was good (60.8), while 31.4 percent were responded negatively while 7.8 percent were in little bit support of migration. There are limited job opportunities in the nation. So, people who are leaving the nation for the employment are found satisfied. Though migration brings remittances and makes people prosperous, it sometime creates problem to people and make them ruin.

\section{Behavioral change of migrant couple}

Human behavior is changeable. Physical facility and social surrounding play important role to shape the habit of an individual. Cultural and financial factors are also affecting behavior of the persons. The following table shows the behavioral change of migrant couple.

Table 8: Behavioral change of migrant couple

\begin{tabular}{|l|c|c|}
\hline \multicolumn{1}{|c|}{ Behavior change } & No of respondents & Percent \\
\hline Yes & 60 & 58.9 \\
\hline No & 30 & 29.4 \\
\hline Not known & 12 & 11.7 \\
\hline Total & 102 & 100.0 \\
\hline
\end{tabular}

Source: Field Survey, 2019 
The above table shows the changing behavior of migrant and his spouse as 58.9 percent were facing the problem of changing behavior while 29.4 percent were experiencing as it was earlier. 11.7 percent respondents were in not known category as they were feeling neither change or not.

Thus, the human behavior could be changed when the socio-cultural and economic situation has been different. The absent of migrant member may cause the change in the behavior in the place of origin.

\section{Behavioral change in migrant's children}

Migration brings remittance along with different positive and negative impact in individuals as well as in family members. Due to the absent of parents and gained money, there would be change in behavior of migrants' children. It might be positive and negative both.

Table 9: Behavioral change of migrants' children

\begin{tabular}{|l|c|c|}
\hline Type of change & No of change & Percent \\
\hline Ask for new cloth and food & 4 & 10 \\
\hline Engage in household activities & 4 & 10 \\
\hline $\begin{array}{l}\text { Not schooling, careless in study/ } \\
\text { work }\end{array}$ & 11 & 27.5 \\
\hline Study and sanitation & 15 & 37.5 \\
\hline Uncontrolled & 6 & 15 \\
\hline Total & 40 & 100 \\
\hline
\end{tabular}

Source: Field Survey, 2019

Out of total respondents 40 replied in positive, 37.5 percent children were seen on positive change demanding the better education, 27.5 percent were related with leaving the school i.e. not schooling, careless in study/work. Similarly, both ask for new clothes and food engage in household activities was 10 percent equally. 15 percent children were uncontrolled and not work properly. More than two third migrant returnees have felt there was change in the behavior of children while more than half were not feeling so which was more clearly mentioned.

\section{Family disruption}

Family disruption is an important part of foreign labo (central bureau of ) (central bureau of )r migration. There are so many cases of family disruption in media i.e. print and electronic. There are many cases of divorce and separation frequently reported by media due to migration. There are headline on newspaper of such cases that migrant's couple left home with money and property, there is nothing while returning at home, someone's wife with others, children are not at school, use of drugs and so on. 
Table: 10 Family disruptions

\begin{tabular}{|c|c|c|}
\hline Feeling of family disruption & No. of respondents & Percent \\
\hline Yes & 30 & 29.4 \\
\hline No & 72 & 71.6 \\
\hline Total & 102 & 100.0 \\
\hline
\end{tabular}

Source: Field Survey, 2019

Among the total respondents 29.6 percent felt about the family disruption and they were thinking so due to changing behavior of family member, illness and torture. Other factors are such as dispute, misunderstanding and quarrel at homes and weak leadership in household and hard to work. Similarly, 71.6 percent were not feeling about family disruption due to migration of husband. They were arguing in favor of not disturbance of family and family as united, equal behavior and understanding in the family.

\section{Conclusion}

The study concludes there has been the behavioral change among the family members of the migrant labors as majority of the respondents agreed with change in the behavior. Similarly, the study studied about the changes in the children of the family and evidenced that majority of the children had gone for better education and also the second largest portion of children were found to be discontinuing in their studies. Further, the study concludes there has not been the family disruption among the family members of the migrant labors.

\section{References}

Battarai, L. N., \& Regmi, S. D. (2012). Role of remittances in rural household economy: A study of western hill, Nepal. Economic Literature.

Central Bureau of Statistics. (2012). Nepal Living Standard Survey 2011/12. Kathmandu: CBS.

Ghimire, H. (2008). A Study of Poverty Allevialtin through Community Organisation in Dolkha District. Kathmandu.

Gurung, G. (2004). An Overview Paper on Overseas Employment in Nepal. Kathmandu: ILO.

Hass, H. D. (2010). Migration and Development: A Theoretical Perspective. International Migration Review , 44 (1), 227-264.

Nepal Human Rights Commission. (2012). Foreign Labour Migration and Trafficking in Persons in Nepal: A Situational Analysis. Kathmandu: NHRC.

Revenstein, G. E. (1885). The Law of Migration. Journal of royal statistical society.

Shrestha, N. R. (2001). The political economy of land, landlessness and migration in Nepal. New Delhi: Nirala Publication.

United Nation Development Programme. (2009). Overcoming Barriers: Human Mobility and Development. New York: UNDP. 